\title{
Myocardial Neoplasm
}

National Cancer Institute

\section{Source}

National Cancer Institute. Myocardial Neoplasm. NCI Thesaurus. Code C5349.

A benign or malignant neoplasm that affects the myocardium. 